Research Paper

\title{
Sensitive droplet digital PCR method for detection of TERT promoter mutations in cell free DNA from patients with metastatic melanoma
}

\author{
Ashleigh C. McEvoy ${ }^{1}$, Leslie Calapre ${ }^{1}$, Michelle R. Pereira ${ }^{1}$, Tindaro Giardina $^{2}$, Cleo \\ Robinson $^{2,3,4}$, Muhammad A. Khattak ${ }^{3,5}$, Tarek M. Meniawy ${ }^{3,6}$, Antonia L. Pritchard7, \\ Nicholas K. Hayward7, Benhur Amanuel',3, Michael Millward ${ }^{3,6}$, Melanie Ziman ${ }^{1,4}$ \\ and Elin S. Gray ${ }^{1}$ \\ ${ }^{1}$ School of Medical and Health Sciences, Edith Cowan University, Joondalup, Western Australia, Australia \\ ${ }^{2}$ Anatomical Pathology, PathWest, QEII Medical Centre, Nedlands, Western Australia, Australia \\ ${ }^{3}$ School of Medicine and Pharmacology, The University of Western Australia, Crawley, Western Australia, Australia \\ ${ }^{4}$ School of Pathology and Laboratory Medicine, University of Western Australia, Crawley, Western Australia, Australia \\ ${ }^{5}$ Department of Medical Oncology, Fiona Stanley Hospital, Murdoch, Western Australia, Australia \\ ${ }^{6}$ Department of Medical Oncology, Sir Charles Gairdner Hospital, Nedlands, Western Australia, Australia \\ ${ }^{7}$ QIMR Berghofer Medical Research Institute, Herston, Brisbane, QLD, Australia \\ Correspondence to: Elin S. Gray, email: e.gray@ecu.edu.au \\ Keywords: droplet digital PCR (ddPCR), TERT, melanoma, cancer \\ Received: June 06, $2017 \quad$ Accepted: July 25, $2017 \quad$ Published: August 18, 2017 \\ Copyright: McEvoy et al. This is an open-access article distributed under the terms of the Creative Commons Attribution License \\ 3.0 (CC BY 3.0), which permits unrestricted use, distribution, and reproduction in any medium, provided the original author and \\ source are credited.
}

\section{ABSTRACT}

Background: Currently mainly BRAF mutant circulating tumor DNA (ctDNA) is utilized to monitor patients with melanoma. TERT promoter mutations are common in various cancers and found in up to $70 \%$ of melanomas, including half of $B R A F$ wildtype cases. Therefore, a sensitive method for detection of TERT promoter mutations would increase the number of patients that could be monitored through ctDNA analysis.

Methods: A droplet digital PCR (ddPCR) assay was designed for the concurrent detection of chr5:1,295,228 C>T and chr5:1,295,250 C > T TERT promoter mutations. The assay was validated using 39 melanoma cell lines and 22 matched plasma and tumor samples. In addition, plasma samples from $\mathbf{5 6}$ metastatic melanoma patients and 56 healthy controls were tested for TERT promoter mutations.

Results: The established ddPCR assay detected TERT promoter mutations with a lower limit of detection (LOD) of $\mathbf{0 . 1 7 \%}$. Total concordance was demonstrated between ddPCR and Sanger sequencing in all cell lines except one, which carried a second mutation within the probe binding-site. Concordance between matched plasma and tumor tissue was $68 \%(15 / 22)$, with a sensitivity of $53 \%$ (95\% CI, $27 \%-$ $79 \%)$ and a specificity of $100 \%$ (95\% CI, 59\%-100\%). A significantly longer PFS $(p=0.028)$ was evident in ctDNA negative patients. Importantly, our TERT promoter mutations ddPCR assay allowed detection of ctDNA in 11 BRAF wild-type cases.

Conclusions: The TERT promoter mutation ddPCR assay offers a sensitive test for molecular analysis of melanoma tumors and ctDNA, with the potential to be applied to other cancers. 


\section{INTRODUCTION}

Telomerase reverse transcriptase (TERT) encodes the catalytic subunit of telomerase, a ribonucleoprotein responsible for maintaining telomere length of chromosomes which play an integral role in cell immortality. Using linkage analysis and high-throughput sequencing, Horn et al. [1] reported somatic mutations in $74 \%$ of metastatic melanoma human cell lines, $85 \%$ of metastatic melanoma tumor tissues and $33 \%$ of primary melanomas. These mutations are the result of a cytidine to thymidine transition in the promoter of the TERT gene, at chromosome 5, $1,295,228 \mathrm{C}>\mathrm{T}$ and 1,295,250 C $>\mathrm{T}$, hereafter termed C228T and $\mathrm{C} 250 \mathrm{~T}$. These mutations create a putative consensus ETS (E26 transformation-specific) /ternary complex factor binding motif (GGAA/T), which is associated with an increase in TERT expression $[1,2]$. The presence of these mutations in cutaneous melanoma is associated with fast growing melanomas [3] and poor prognosis [4]. The co-existence of TERT promoter mutations with $B R A F$ or $N R A S$ mutations (in $55 \%$ of cases) is associated with poor disease-free and melanoma-specific survival [5]. TERT promoter mutations occur frequently in a number of other cancers: $80-90 \%$ of glioblastoma multiforme, $60 \%$ of hepatocellular carcinoma, $60 \%$ of bladder cancer, $70 \%$ of basal cell carcinoma, $50 \%$ of cutaneous squamous cell carcinoma and up to $30 \%$ of thyroid cancers [6-11] and are associated with aggressive disease in thyroid carcinoma [12], glioblastoma [13], neuroblastoma [14] and renal cell carcinoma [15]. Therefore, it is of significant clinical benefit to develop a non-invasive and sensitive test that determines the TERT promoter mutation status in cancer patients.

Molecular profiling of tumors to aid cancer prognosis and to identify actionable therapeutic targets has become routine practice in clinical oncology. Whilst tumor tissue samples are typically used for mutation analysis, access to the tumor for biopsy, and the quality and quantity of the sample may hinder detection, particularly when methods with limited sensitivity are employed. Commonly used methods include Sanger sequencing, melting curve analysis and pyrosequencing which have limits of sensitivity of $15 \%-20 \%, 10 \%$ and $5 \%$ respectively [16]. More recently, tumor related aberrations have been determined in plasma cell free DNA (cfDNA) [17-22]. This is referred to as "liquid biopsy", a relatively noninvasive test that can be performed regularly and provides information from the sum of all tumors at any one time point. It is, therefore, a valuable biomarker for monitoring disease progression and response to therapy [19, 23].

Whilst a variety of methods have been used to detect mutations from circulating tumor DNA (ctDNA), Hindson et al., have shown droplet digital PCR (ddPCR) to be a highly sensitive platform, enabling absolute quantitation of mutant BRAF down to $0.001 \%$ allelic fraction [24]. Various studies have since shown the utility of testing mutant $B R A F$ in plasma of melanoma patients using
ddPCR [18, 23, 25-27]. In particular, our laboratory has demonstrated that ctDNA analysis allows tracking of patient response to therapy and resistance acquisition [23]. Given the high prevalence of the TERT promoter mutations $\mathrm{C} 228 \mathrm{~T}$ and $\mathrm{C} 250 \mathrm{~T}$ in cutaneous melanoma $[5,28]$, their addition to existing tests for detection of mutant $B R A F$ and NRAS will allow monitoring of most melanoma patients using ddPCR. Furthermore, it has been shown that concurrence of mutations in the TERT promoter with $B R A F$ or $N R A S$ mutations predispose patients to fast growing and aggressive disease, thus detection of multiple mutations including mutant TERT could serve as a prognostic marker.

We report here on the development of a ddPCR probe based assay to simultaneously detect the TERT promoter mutations $\mathrm{C} 250 \mathrm{~T}$ and $\mathrm{C} 228 \mathrm{~T}$. One probe binds the wild-type sequence overlapping position $\mathrm{C} 228$, while a second probe binds the mutant sequence resulting from $\mathrm{C} 228 \mathrm{~T}$ or $\mathrm{C} 250 \mathrm{~T}$ mutations, as both mutations reconstitute the putative ETS binding site (Figure 1). First, we tested the concordance of this assay for the detection of TERT promoter mutations in 39 melanoma cell lines relative to Sanger sequencing, and in 22 plasma samples relative to patient matched tumor tissue. We also determined the sensitivity and specificity of this assay for the detection of TERT promoter mutations using plasma derived cfDNA from 56 melanoma patients and 56 healthy controls.

\section{RESULTS}

The designed primer sets were tested for amplification of the genomic region of interest by end-point PCR. Amplification conditions were optimized by testing a range of annealing temperatures $\left(55-61^{\circ} \mathrm{C}\right)$. As shown in Figure $2 \mathrm{~A}$, the primers failed to amplify the required fragment in the absence of Q-solution (Qiagen). Optimal amplification was achieved in the presence of Q-solution between $61-64^{\circ} \mathrm{C}$ (Figure 2B). The PCR fragment obtained was subjected to Sanger sequencing to confirm its specificity.

Next, droplet digital PCRs were performed at a gradient of annealing temperatures from $52^{\circ} \mathrm{C}$ to $65^{\circ} \mathrm{C}$ for the detection of the $\mathrm{C} 228 \mathrm{~T}$ mutation in gDNA from 1205 Lu cells (Figure 2C and 2D) and the $\mathrm{C} 250 \mathrm{~T}$ mutation in gDNA from UACC62 cells (Figure 2E and 2F). Optimal droplet segregation was observed at $57^{\circ} \mathrm{C}$. Hereafter all ddPCR assays were performed with an annealing/ extension temperature of $57^{\circ} \mathrm{C}$.

To evaluate the quantitative linearity and the limit of detection (LOD) of the ddPCR assay, serial dilutions of mutant gDNA from cell lines 1205Lu (C228T mutant) and UACC62 (C250T mutant) were mixed in a background of wild-type human genomic DNA to achieve a final concentration of gDNA of $20 \mathrm{ng} / \mu \mathrm{L}$ (Figure 3), with each dilution tested in 8 replicates. At $0 \%$ mutant DNA, we identified that a maximum of 2 false positive droplets were observed in some of the 8 replicates, with an average of 
$0.068 \pm 0.049 \%$. Therefore, the lower LOD was defined at $0.17 \%$, the percentage false positives detectable at two standard deviations over mean background [29].

To validate the assay, we tested 39 cell lines with known TERT promoter mutant or wild-type status (Table 1). We confirmed detection of the C228T and/or the C250T TERT promoter mutation in only those cell lines identified as positive for these two mutations, while those previously identified as wild-type showed no positivity for TERT DNA mutations by ddPCR. Cell lines that harbored an alternative TERT mutation other than C228T or C250T showed as wild-type in our assay. In addition, the C250T mutation was not detected in cell line C021, due to the presence of a C253T single nucleotide polymorphism in the probe binding site (Supplementary Figure 1). Simultaneous C250T and C253T mutations have been reported in $2 \%$ of melanoma cells lines [1].

Tumor tissue samples from 22 stage IV (AJCC) metastatic melanoma patients were tested for C228T and C250T TERT promoter mutations by ddPCR using the TERT assay (Table 2). As reported in the literature [4, 28, $30]$, most tumor tissues tested harbored at least one of these mutations $(68 \%, \mathrm{n}=15) ; 11$ harbored the $\mathrm{C} 228 \mathrm{~T}$ mutation and 4 harbored the C250T mutation. No tissue samples were found to contain both TERT promoter mutations.

Plasma derived cfDNA from these 22 patients were also tested for TERT promoter mutations. These plasma samples were collected from patients with active metastatic disease prior to any systemic therapeutic intervention. Overall, the concordance rate between tumor tissue and plasma testing was $68 \%(15 / 22)$. No patient was positive for a TERT promoter mutation in plasma and negative in its corresponding tumor tissue $(100 \%$ specificity). Of 15 plasmas from patients with confirmed TERT promoter positive tumors, 8 were identified as positive for the same mutation, whereas 7 cases were positive in the tissue but negative in the plasma sample (Table 2). Thus, the sensitivity of our TERT C228T/C250T mutation detection in plasma was estimated as 53\% $(95 \%$ CI $27 \%-79 \%$ ). In a cox regression analysis, patients with detectable ctDNA at baseline $(n=8)$ had a significantly shorter progression free survival (PFS) compared to patients that had no detectable ctDNA $(\mathrm{n}=7)(p=0.028$, Hazard ratio: 4.48 (CI, 1.18-17.06) (Figure 4A).

To further demonstrate the detection rate of TERT ctDNA in metastatic melanoma we tested 56 plasma samples from randomly selected stage IV (AJCC) melanoma patients (mean age 65 years, ranging from 35 to 85 years) with known $B R A F$ but unknown TERT mutational status and compared this to 56 plasma samples from healthy individuals (mean age 51 years, ranging from 24 to 81 years). The TERT ddPCR assay detected a statistically significant difference in the copies of mutant TERT ctDNA in plasma from metastatic melanoma patients relative to those from healthy controls $(\mathrm{p}=0.006$, Figure 4). We found TERT mutant DNA in 11 of $38 B R A F$ wild-type and in 4 of the $18 B R A F \mathrm{~V} 600 \mathrm{E} / \mathrm{K}$ patients. The number of TERT promoter copies per $\mathrm{mL}$ of plasma detected in the melanoma patient cohort varied from 11.2 to 176 copies per $\mathrm{mL}$ (Figure 4). No TERT promoter mutant DNA was detected in any of the 56 healthy control plasmas. Based on these results the assay specificity was estimated as 100\% (95\% CI 94\%-100\%).

\section{DISCUSSION}

Here we describe and validate a method to detect the two most common TERT promoter mutations found in melanoma tumors using ddPCR. TERT promoter mutations occur in melanoma as frequently as [4], or more frequently [5] than $B R A F$ mutations, and yet mainly $B R A F$ mutant specific cfDNA is being used to monitor melanoma patients for response to therapy and disease progression [26]. The inclusion of TERT promoter mutations within ctDNA for monitoring would increase the number of patients for whom ctDNA could be used to determine

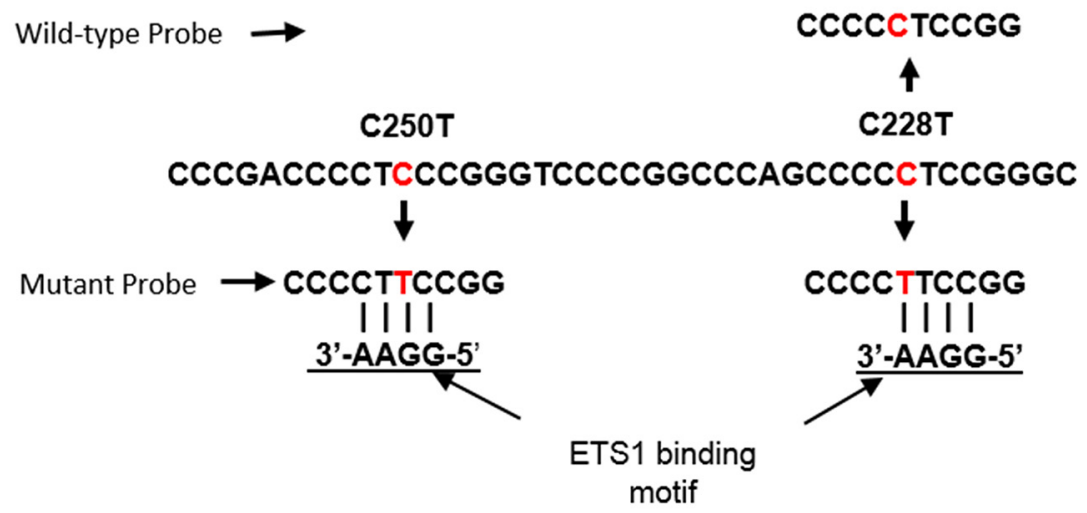

Figure 1: Location of ddPCR assay probes relative to ETS1 binding motifs generated by the C228T and C250T TERT promoter mutations. Probes for the identification of wild-type and mutant sequences are indicated. Both mutant sites are detected by the same probe. 
disease status, particularly amongst $B R A F$ and $N R A S$ wildtype melanoma patients. This will enable large studies on the clinical utility of ctDNA monitoring to provide evidence of the efficacy of this marker for determining disease progression, to inform cessation of ineffective therapies $[23,27]$ and to guide alternative therapy.

Our assay allowed for detection of mutant TERT in biologically relevant samples, such as FFPE tumor DNA and plasma of metastatic melanoma patients at high specificity. Using cell line derived DNA, we optimized the assay to detect as little as $0.17 \%$ mutant TERT DNA in dilutions of wild-type DNA. This is significantly lower than limits of detection reported for other mutation detection platforms such as allele specific PCR at 1\% [31] and pyrosequencing at 5\%, melting curve analysis at $10 \%$ and Sanger sequencing at 20\% [16]. While we and others have shown ddPCR to detect $B R A F$ mutant fraction as low as $0.001 \%[24,32]$, we were unable to achieve this sensitivity with the TERT assay developed here, possibly due to the highly GC rich area of the promoter region of this gene, resulting in background signal and limited segregation of positive and negative droplets. In fact, during the development of this assay, multiple primers, probes and amplification conditions were tested without success. The conditions detailed here, including the addition of LNA at the specific nucleotides and the use of Q-solution in the amplification mix, were indispensable for successful amplification.

We validated the assay in terms of accuracy and reliability by showing $97.4 \%$ concordance with the genotype of 39 melanoma cell lines. Of the cell lines analyzed that harbored either a C228T or C250T
A
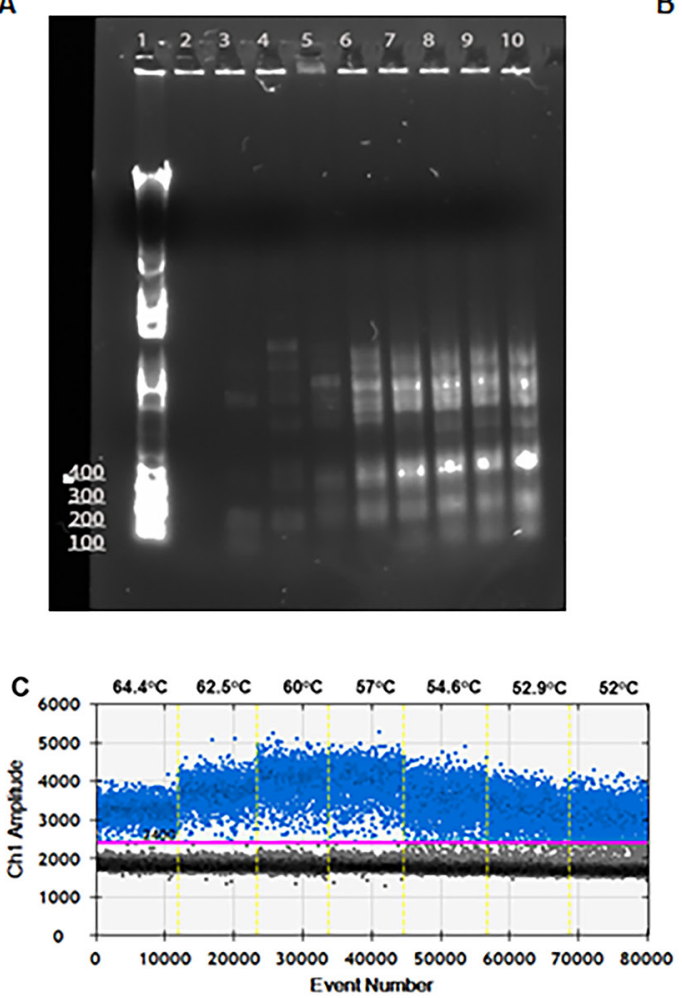

E

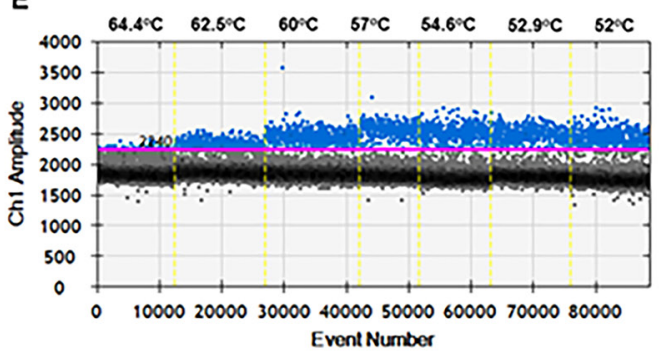

B
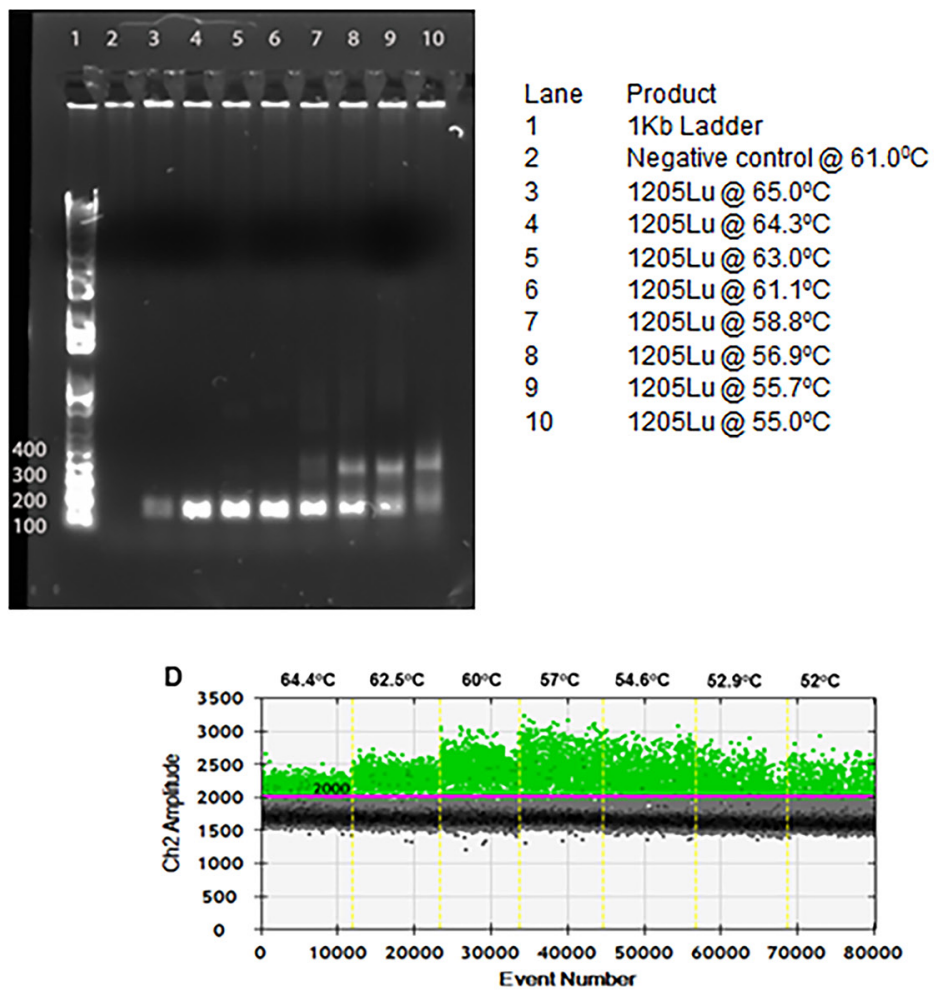

F

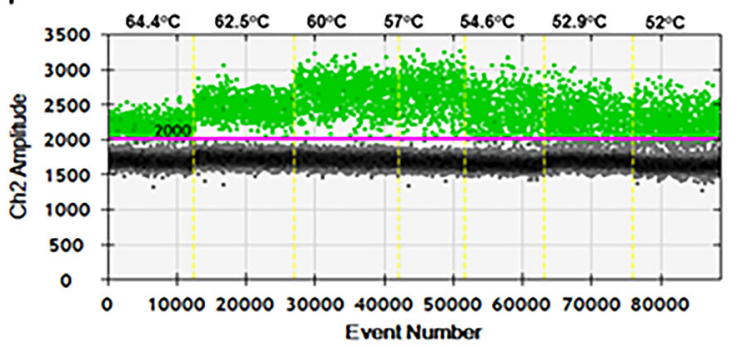

Figure 2: Optimization of ddPCR for detection of TERT promoter mutations. PCR fragments from cell line $1205 \mathrm{Lu}$ amplified at varying temperatures without (A) and with (B) "Q solution". gDNA of cell lines 1205Lu-C228T (C and D) and UACC62-C250T (E and F) were used as template for the TERT ddPCR at varying annealing temperatures. FAM signal from mutant probe binding to $\mathrm{C} 228 \mathrm{~T}(\mathrm{C})$ or $\mathrm{C} 250 \mathrm{~T}$ (E). HEX signal from binding of wild-type probe (D and F). 
mutation, 14 were heterozygous and 9 homozygous. A major limitation of our assay is that it cannot detect other TERT promoter mutations and it can be affected by SNPs within the probe binding sites. This was apparent by the results obtained from 9 cell lines with known TERT promoter dinucleotide mutations C227T/C228T and $\mathrm{C} 241 \mathrm{~T} / \mathrm{C} 242 \mathrm{~T}$, which have been reported to exist in $5.2 \%$ and $10.4 \%$ of primary melanomas respectively [1]. Similarly, a negative result was reported for cell line CO12 which harbors a C253T SNP on the probe binding site. Further development of ddPCR assays to detect these other TERT promoter mutations [5] would ensure that a maximum number of patients could be monitored. In addition and given that SNPs in this region can also affect patient prognosis [5], germline sequence analysis should be performed complementary to the analysis of TERT promoter somatic mutations.

It is notable that all patients with TERT promoter mutations in plasma had corresponding mutations in matched tumor tissue and as such no false positive plasma samples were detected. High concordance between mutational profiles in plasma ctDNA and matched tumor tissue have been reported in several studies from patients with melanoma $[18,25,26]$, breast cancer [20, 33, 34],
A

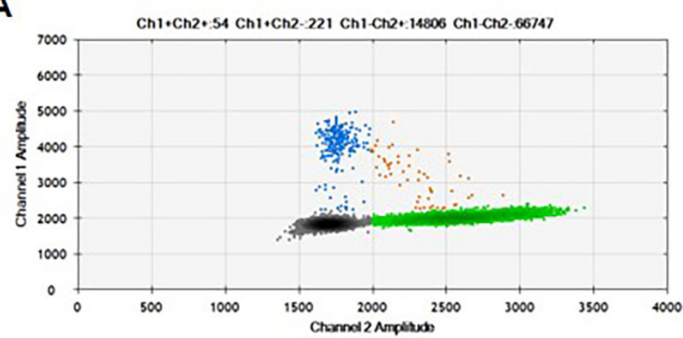

B

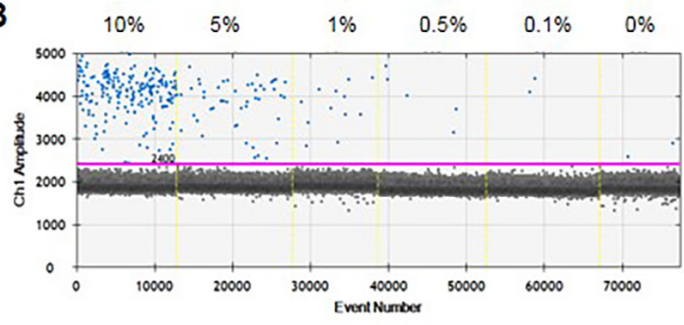

C

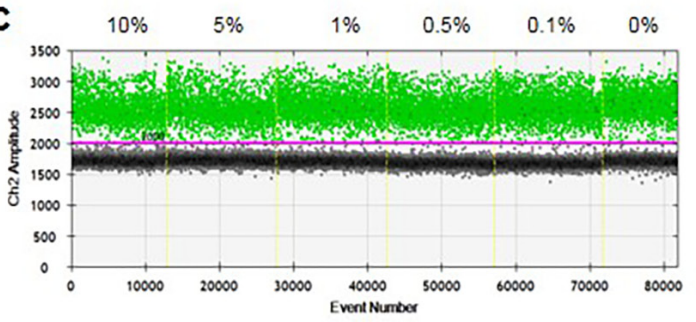

D

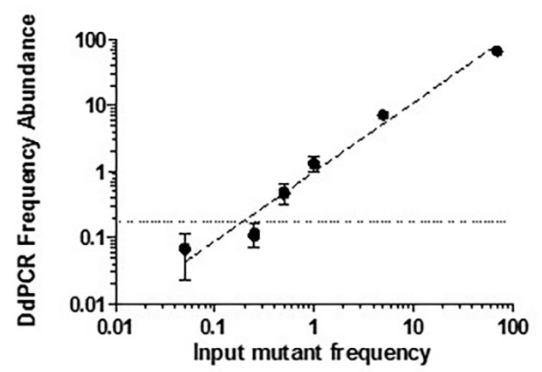

E

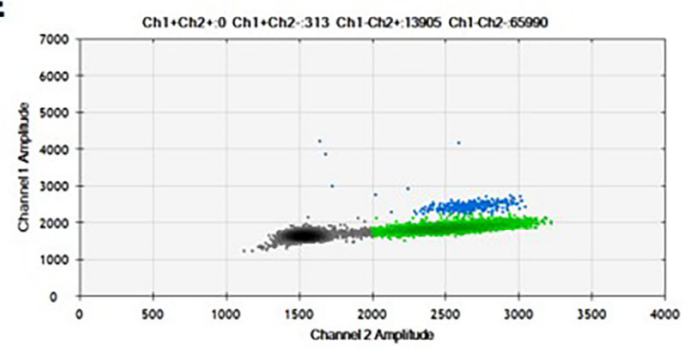

$\mathbf{F}$

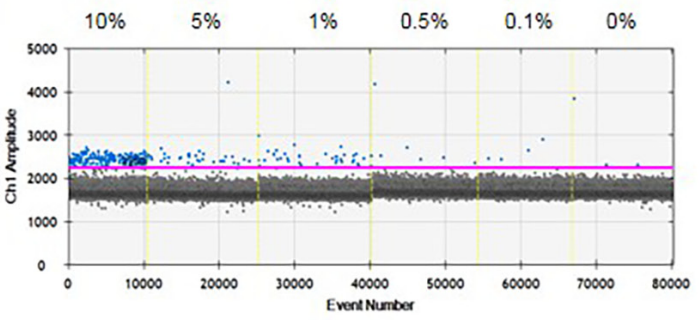

G

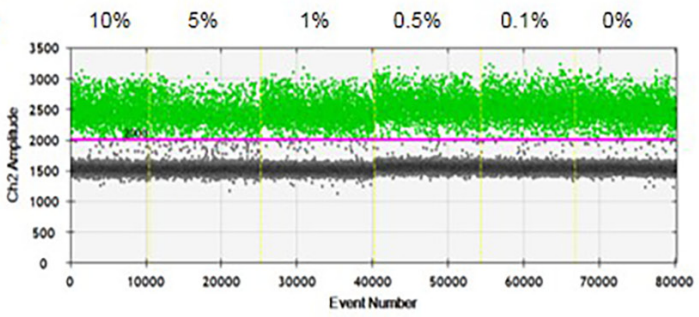

H

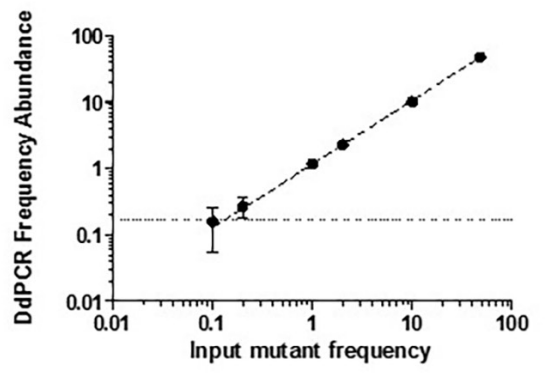

Figure 3: Detection of TERT promoter mutations in the presence of homologous wild-type DNA. Serial dilutions of DNA from mutant cell lines 1205Lu - C228T (A-D) and UACC62 - C250T (E-H) were prepared in a constant background of wild-type human genomic DNA. 2D plots of ddPCR read out at 10\% of mutant DNA (A and E). 1D plots indicating mutant (B and F) and wild-type (C and G) DNA detection. Analytical sensitivity (LOD) of the assay (D and H). Obtained frequency abundances and standard deviations were plotted versus expected mutant frequencies based on input. The LOD, defined as 2 SD over the mean frequency abundance obtained at $0 \%$ when only wild-type DNA was used as input, was indicated as dashed lines in both graphs. 
Table 1: Validation of C228T and C250T TERT promoter mutation detection in melanoma cell lines

\begin{tabular}{|c|c|c|}
\hline Cell line & Sanger sequencing & ddPCR \\
\hline $\mathrm{C} 024$ & wt & wt \\
\hline $\mathrm{C} 055$ & wt & wt \\
\hline C092 & wt & wt \\
\hline $\mathrm{C} 096$ & wt & wt \\
\hline HGA & wt & wt \\
\hline $\mathrm{C} 022$ & $\mathrm{C} 228 \mathrm{~T}$ & $\mathrm{C} 228 \mathrm{~T}$ \\
\hline $\mathrm{C} 037$ & $\mathrm{C} 228 \mathrm{~T}$ & $\mathrm{C} 228 \mathrm{~T}$ \\
\hline $\mathrm{C} 058$ & $\mathrm{C} 228 \mathrm{~T}$ & $\mathrm{C} 228 \mathrm{~T}$ \\
\hline D41 & $\mathrm{C} 228 \mathrm{~T}$ & $\mathrm{C} 228 \mathrm{~T}$ \\
\hline MM409 & $\mathrm{C} 228 \mathrm{~T}$ & $\mathrm{C} 228 \mathrm{~T}$ \\
\hline D22 & $\mathrm{C} 228 \mathrm{~T}$ & $\mathrm{C} 228 \mathrm{~T}$ \\
\hline MM473 & $\mathrm{C} 228 \mathrm{~T}$ & $\mathrm{C} 228 \mathrm{~T}$ \\
\hline A06 & $\mathrm{C} 228 \mathrm{~T}^{a}$ & $\mathrm{C} 228 \mathrm{~T}^{a}$ \\
\hline $\mathrm{C} 076$ & $\mathrm{C} 228 \mathrm{~T}^{a}$ & $\mathrm{C} 228 \mathrm{~T}^{a}$ \\
\hline MM455 & $\mathrm{C} 228 \mathrm{~T}^{a}$ & $\mathrm{C} 228 \mathrm{~T}^{a}$ \\
\hline $1205 \mathrm{Lu}$ & $\mathrm{C} 228 \mathrm{~T}^{a}$ & $\mathrm{C} 228 \mathrm{~T}^{a}$ \\
\hline A15 & $\mathrm{C} 250 \mathrm{~T}$ & $\mathrm{C} 250 \mathrm{~T}$ \\
\hline A14 & $\mathrm{C} 250 \mathrm{~T}$ & $\mathrm{C} 250 \mathrm{~T}$ \\
\hline $\mathrm{C} 002$ & $\mathrm{C} 250 \mathrm{~T}$ & $\mathrm{C} 250 \mathrm{~T}$ \\
\hline MM537 & $\mathrm{C} 250 \mathrm{~T}$ & $\mathrm{C} 250 \mathrm{~T}$ \\
\hline SKMEL13 & $\mathrm{C} 250 \mathrm{~T}$ & $\mathrm{C} 250 \mathrm{~T}$ \\
\hline MM386 & $\mathrm{C} 250 \mathrm{~T}$ & $\mathrm{C} 250 \mathrm{~T}$ \\
\hline D01 & $\mathrm{C} 250 \mathrm{~T}$ & $\mathrm{C} 250 \mathrm{~T}$ \\
\hline MM229 & $\mathrm{C} 250 \mathrm{~T}^{a}$ & $\mathrm{C} 250 \mathrm{~T}^{a}$ \\
\hline MM253 & $\mathrm{C} 250 \mathrm{~T}^{a}$ & $\mathrm{C} 250 \mathrm{~T}^{a}$ \\
\hline MM266 & $\mathrm{C} 250 \mathrm{~T}^{a}$ & $\mathrm{C} 250 \mathrm{~T}^{a}$ \\
\hline $\mathrm{C} 001$ & $\mathrm{C} 250 \mathrm{~T}^{a}$ & $\mathrm{C} 250 \mathrm{~T}^{a}$ \\
\hline $\mathrm{C} 045$ & $\mathrm{C} 250 \mathrm{~T}^{a}$ & $\mathrm{C} 250 \mathrm{~T}^{a}$ \\
\hline D40 & $\mathrm{C} 250 \mathrm{~T}^{a}$ & $\mathrm{C} 250 \mathrm{~T}^{a}$ \\
\hline UACC62 & $\mathrm{C} 250 \mathrm{~T}^{a}$ & $\mathrm{C} 250 \mathrm{~T}^{a}$ \\
\hline MM396 & $\mathrm{C} 227 \mathrm{~T} / \mathrm{C} 228 \mathrm{~T}$ & $\mathrm{wt}$ \\
\hline A07 & $\mathrm{C} 227 \mathrm{~T} / \mathrm{C} 228 \mathrm{~T}$ & wt \\
\hline $\mathrm{C} 054$ & $\mathrm{C} 227 \mathrm{~T} / \mathrm{C} 228 \mathrm{~T}$ & wt \\
\hline $\mathrm{C} 062$ & $\mathrm{C} 227 \mathrm{~T} / \mathrm{C} 228 \mathrm{~T}$ & wt \\
\hline $\mathrm{C} 057$ & $\mathrm{C} 241 \mathrm{~T} / \mathrm{C} 242 \mathrm{~T}$ & wt \\
\hline $\mathrm{C} 108$ & $\mathrm{C} 241 \mathrm{~T} / \mathrm{C} 242 \mathrm{~T}$ & wt \\
\hline D28 & $\mathrm{C} 241 \mathrm{~T} / \mathrm{C} 242 \mathrm{~T}$ & wt \\
\hline SKMEL5 & $\mathrm{C} 241 \mathrm{~T} / \mathrm{C} 242 \mathrm{~T}$ & wt \\
\hline $\mathrm{C} 021$ & $\mathrm{C} 250 \mathrm{~T}^{b}$ & wt \\
\hline
\end{tabular}

aHomozygous

${ }^{\mathrm{b}} \mathrm{C} 021$ carried an additional C253T polymorphism. 
Table 2: Detection of TERT promoter mutations in ctDNA and paired tumor tissue

\begin{tabular}{lcccc}
\hline & \multicolumn{3}{c}{ Tumor Tissue } & \\
\cline { 2 - 5 } & Plasma ctDNA & + & - & Total \\
\hline+ & 8 & 0 & 8 \\
- & 7 & 7 & 14 \\
Total & 15 & 7 & 22 \\
\hline
\end{tabular}

non-small cell lung cancer $[35,36]$ and colorectal cancer $[17,20,37]$. In our study, 7 patients with TERT promoter positive tumors had no detectable TERT promoter mutations in matched plasma samples. This is similar to the findings by Lee et al, who detected ctDNA in $53 \%$ of patients prior to treatment initiation [38]. The lack of detectable ctDNA in a subset of patients may be explained by the pathophysiology of the tumor or its metastasis, as ctDNA concentration has been correlated with tumor size [38-40], metastatic spread or disease burden $[25,38,41]$, tumor vascularization [42] and site of metastasis [20]. A retrospective analysis of PFS in this group of patients revealed a significant difference between patients with negative and positive ctDNA results. This further supports previous findings that low or undetectable level of ctDNA is a predictor of long term treatment benefit $[18,23,25,26,38]$.

Previous studies have reported detection rates for $B R A F \mathrm{~V} 600 \mathrm{E}$ mutations in plasma of metastatic patients at 76 to $84.3 \%[25,26]$ and for $B R A F \mathrm{~V} 600 \mathrm{~K}$ at 81 to $89 \%[18,26]$. In other cancers, Bettegowda et al. [20] identified mutant ctDNA in $75 \%$ of patients with a variety of cancers including ovarian, breast, bladder, gastroesophageal and colorectal cancers. Considering our detection rates of TERT promoter mutations in ctDNA are lower $(53 \%)$ than these reports, it would be necessary for this investigation to be conducted in a larger cohort controlling for tumor burden, metastatic sites and mutation variety. Nevertheless, our TERT promoter mutation assay allowed ctDNA detection in 11 of $38 B R A F$ wild-type tumors. Thus, our assay may facilitate ctDNA monitoring on $B R A F$ wild-type cases, most of which will receive immunotherapy as a first line of treatment.

Nagore and colleagues [5] have shown that melanoma patients harboring these specific TERT promoter mutations, in combination with $B R A F / N R A S$ mutations within their tumor tissue, have a significantly shorter disease free survival than patients without this combination. In fact, Li et al., have shown that TERT promoter mutations are key downstream targets of the RAS-ERK pathway for malignant progression of $B R A F$ mutant melanomas [43]. Furthermore, Akincilar et al. [44] have shown that TERT transcription is driven by mediation of long-range chromatin interaction and enrichment of active histone marks through the recruitment of GABPA to mutant TERT promoters, specifically C228T and C250T. These authors have consequently suggested that inhibitors could be designed to hinder TERT transcription in cancer cells with these mutations. As such, routine genetic testing of melanoma patients for TERT promoter mutations in addition to mutant $B R A F$ and NRAS would be clinically beneficial.

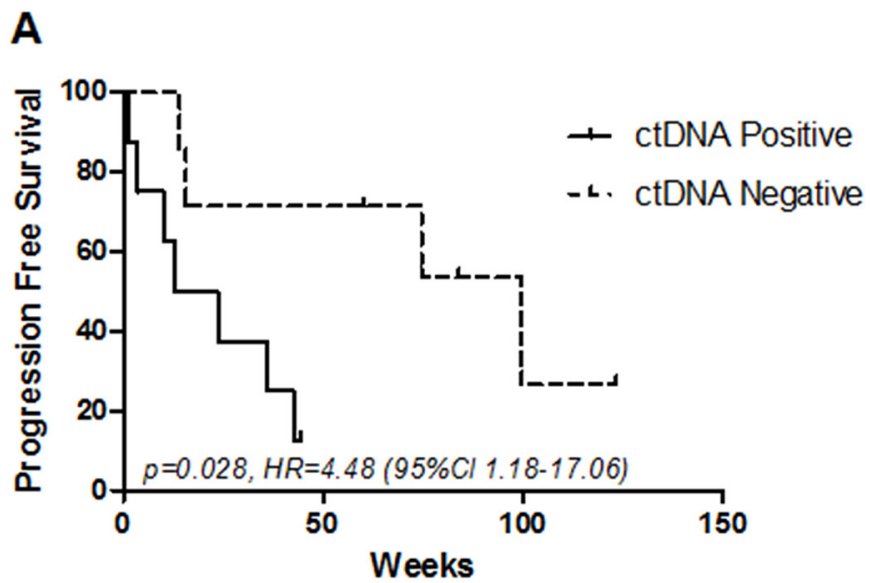

B

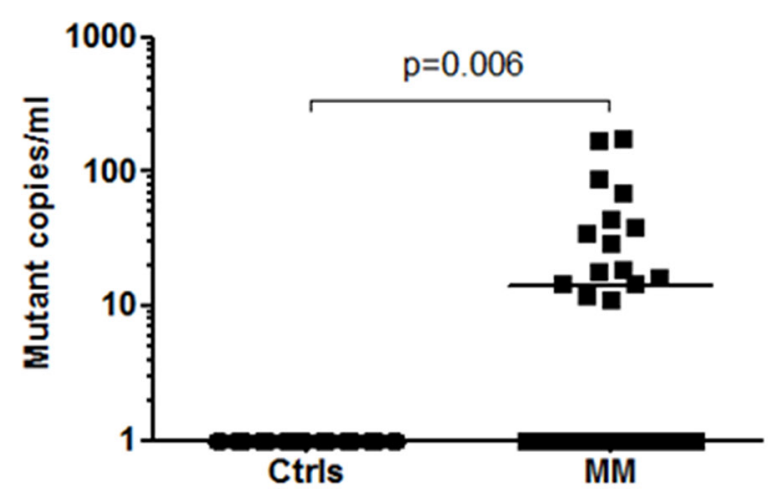

Figure 4: Detection of $\boldsymbol{T E R T}$ promoter mutations in plasma. (A) Kaplan-Meier plots of PFS probabilities of patients with detectable $(n=8)$ and undetectable $(n=7)$ ctDNA levels at baseline. Cox regression p-value, Hazard ratio (HR) and confidence interval (CI) are indicated. (B) Copies of mutant DNA per $\mathrm{mL}$ of plasma were significantly higher in metastatic melanoma patients $(\mathrm{MM})(\mathrm{N}=56)$ compared to healthy controls $(\mathrm{Ctrls})(\mathrm{N}=56) . \mathrm{P}=0.006$, Mann-Whitney U-test. 
TERT promoter mutations have been identified in numerous other cancers such as thyroid, bladder, hepatocellular cancer and malignant glioblastoma [6-8]. Consequently, the assay described here may allow ctDNA monitoring in multiple other malignancies. However, the assay would require validation for each of these cancers.

In conclusion, we report on the development of a ddPCR assay for the detection of two common TERT promoter mutations in cell lines, tumor tissue and ctDNA. Our results suggest that the TERT ddPCR assay could prove useful as a companion diagnostic to predict treatment benefit and to monitor response in melanoma patients and could be extended to other malignancies.

\section{MATERIALS AND METHODS}

\section{Ethics}

This study was approved by the Human Ethics Committees at Edith Cowan University (No. 11543) and Sir Charles Gairdner Hospital (No.2013-246).

\section{Genomic DNA extraction}

Genomic DNA (gDNA) with known TERT promoter mutations was obtained from melanoma cell lines $1205 \mathrm{Lu}$ (Wistar Institute) and UACC62 (National Cancer Institute) to be used as positive controls. In addition, gDNA was extracted from 39 melanoma cell lines from the QIMR Berghofer Medical Research Institute [45]. Wild-type gDNA was obtained from the white blood cell pellets collected from $4 \mathrm{~mL}$ whole blood from one healthy control. DNA was isolated using the QIAamp DNA Mini Kit (Qiagen, Australia) as per the manufacturer's instructions. gDNA was eluted in AE buffer (Qiagen) and stored at $4^{\circ} \mathrm{C}$ until further processing.

\section{Plasma sample preparation}

Blood samples were collected from American Joint Committee on Cancer (AJCC) stage IV melanoma patients, prior to initiation of any systemic therapy, into EDTA vacutainer tubes and stored at $4^{\circ} \mathrm{C}$. Plasma was separated within 24 hours by centrifugation at $1600 \mathrm{~g}$ for 10 minutes, followed by a second centrifugation at $2000 \mathrm{~g}$ for 10 minutes, then stored at $-80^{\circ} \mathrm{C}$ until extraction.

\section{DNA extraction from plasma}

cfDNA was isolated from $5 \mathrm{~mL}$ of plasma from healthy donors and AJCC stage IV metastatic melanoma patients using the QIAamp Circulating Nucleic Acid Kit (Qiagen) as per the manufacturer's instructions. cfDNA was eluted in $40 \mu \mathrm{l}$ AVE buffer (Qiagen) and stored at $-80^{\circ} \mathrm{C}$ until ctDNA quantification.

\section{DNA extraction from FFPE tissue}

Following review and macrodissection by an experienced pathologist, genomic DNA (gDNA) was extracted from $10 \times 5 \mu \mathrm{m}$ unstained sections of FFPE tissue using the QIAamp DNA mini kit (Qiagen) as per the manufacturer's instructions. Only FFPE tissues stored at room temperature, for less than 7 years were used. The DNA concentration and purity was determined using the NanoDrop ND-1000 spectrophotometer (NanoDrop Technologies, Wilmington, DE) and Qubit 2.0 Fluorometer (Life Technologies, USA) instruments.

\section{PCR}

The following primers were used to amplify a $163 \mathrm{bp}$ product incorporating both hotspot mutations (C228T and C250T) in the TERT promoter region: 5'AGCGCTGCCTGAAACTCG -3' (forward) and 5'CCTGCCCCTTCACCTTCCAG -3' (reverse). Primers were synthesized by GeneWorks (Thebarton, SA, Australia). For optimization of the PCR amplification of TERT promoter mutations, we first performed end point PCRs containing, $1 \mathrm{x}$ ddPCR supermix (Bio-Rad), 900 $\mathrm{nM}$ of each primer and $50 \mathrm{ng}$ of template gDNA, with and without $1 \times$ Q solution (Qiagen). Amplifications were performed using the following cycling conditions: 1 cycle of $95^{\circ} \mathrm{C}$ for 15 minutes, 40 cycles of $95^{\circ} \mathrm{C}$ for 30 seconds and a range of temperatures from $55^{\circ} \mathrm{C}$ to $65^{\circ} \mathrm{C}$ for 30 seconds, followed by $68^{\circ} \mathrm{C}$ for 30 seconds and 1 cycle of $68^{\circ} \mathrm{C}$ for 10 minutes. PCR products of $163 \mathrm{bp}$ were detected by gel electrophoresis on a $1 \%$ agarose gel in Tris-acetate-EDTA (TAE) buffer containing SYBR ${ }^{\circledR}$ Safe DNA Gel Stain (Life Technologies).

\section{Droplet digital PCR}

A probe was designed to detect both $\mathrm{C} 228 \mathrm{~T}$ and C250T mutation as both mutations result in the same sequencing string (Figure 1). Due to the short size of the probe, Locked Nucleic Acid (LNA) bases were introduced on the bases indicated with a "+" (TERT Mut:/56-FAM/CCC+C+T+T+CCGG/3IABkFQ/).

A second probe was designed to recognize the $\mathrm{C} 228$ loci, also containing LNA bases, (TERT WT, /5HEX/ $\mathrm{CCCC}+\mathrm{C}+\mathrm{T}+\mathrm{CCGG} / 3 \mathrm{IABkFQ} /$ ). Probes were custom synthesized by Integrated DNA Technologies (IDT). Amplifications were performed in a $20 \mu \mathrm{L}$ reaction containing $1 \mathrm{x}$ ddPCR Supermix for Probes (No dUTP, Bio-Rad), 1x Q solution (Qiagen), $250 \mathrm{nM}$ of each probe and $900 \mathrm{nM}$ of each primer plus template.

Droplets were generated using the Automatic Droplet generator QX200 AutoDG (Bio-Rad). Amplifications were performed using the following cycling conditions: 1 cycle of $95^{\circ} \mathrm{C}(2.5 \mathrm{C} / \mathrm{s}$ ramp $)$ for 
10 minutes, 40 cycles of $94^{\circ} \mathrm{C}(2.5 \mathrm{C} / \mathrm{s}$ ramp $)$ for 30 seconds and $57^{\circ} \mathrm{C}$ for 1 minute, followed by 1 cycle of $98^{\circ} \mathrm{C}(2.5 \mathrm{C} / \mathrm{s}$ ramp $)$ for 10 minutes. Annealing/extension temperature was optimized using temperature gradients from $52^{\circ} \mathrm{C}$ to $65^{\circ} \mathrm{C}$. The sample was held at $4{ }^{\circ} \mathrm{C}$ until further processing. Droplets were analyzed through a QX200 droplet reader (Bio-Rad). QuantaSoft analysis software (Bio-Rad) was used to acquire and analyze data.

To evaluate the LOD of our TERT ddPCR assay, gDNA from cell lines 1205Lu (C228T) or UACC62 (C250T) were serially diluted into normal human DNA obtained from white blood cells of healthy controls to achieve from $100 \%$ to $0 \%$ mutant alleles. Each dilution was tested in a series of eight repetitions all completed in one run.

Cell lines with known C228T and C250T TERT promoter mutations, as well as cell lines wild-type for both mutations (as determined by Sanger sequencing) were used to validate the assay. The reaction mix was prepared as above using $50 \mathrm{ng}$ of gDNA as template.

For plasma ctDNA analysis, $5 \mu \mathrm{L}$ of cfDNA (maximum template volume possible) was added per reaction irrespective of the cfDNA concentration. Each run included a non-template control, gDNA from a healthy control and gDNA from the cell lines containing the TERT mutations: 1205Lu (C228T) and UACC62 (C250T). Only samples with more than two positive droplets were considered positive. The number of mutated DNA copies per $20 \mu \mathrm{l}$ reaction was extrapolated to calculate copies per $\mathrm{mL}$ using the following equation:

Copies $/ \mathrm{mL}$ of plasma $=\mathrm{C}^{*} \mathrm{EV} / \mathrm{TV} / \mathrm{PV}$.

$\mathrm{PV}=$ Volume of plasma used for cfDNA extraction $(\mathrm{ml})$

$\mathrm{EV}=$ Volume in which cfDNA was eluted $(\mu \mathrm{l})$

$\mathrm{TV}=$ Volume of cfDNA added to the PCR reaction $(\mu \mathrm{l})$ $\mathrm{C}=$ copies $/ 20 \mu \mathrm{l}$ (data derived from QuantaSoft).

\section{Statistical analysis}

Sensitivity and specificity of the assay was calculated using a contingency table analyzed using a Fisher's exact test. Comparison between ctDNA concentrations in patient and control samples were performed using the non-parametric Mann-Whitney $U$-test. A Cox proportional hazards regression analysis was performed to examine association of ctDNA detection with PFS. Statistical analyses were performed using Statistical Package for Social Sciences for Window version 22 (SPSS, Chicago, IL) and plotted using GraphPad Prism version 5.

\section{Author contributions}

All authors contributed to the work presented in this study and reviewed the final manuscript. ACM designed the study, performed experiments, analyzed data and wrote the manuscript. LC, MP, TG, CR performed experiments and analyzed data. BA analyzed samples and provided expert advice. MAK, TMM and MM recruited and clinically assessed patients and provided clinical information. ALP and NKH supplied material, genetic data and provided expert advice. MZ and ESG designed experiments, analyzed data, supervised the study and wrote the paper.

\section{ACKNOWLEDGMENTS}

The authors thank all the participants, patients and healthy volunteers, for their assistance with the study. We also would like to thank Ms Sarah Wickham for her assistance with data collection.

\section{CONFLICTS OF INTEREST}

No author has any conflicts of interest to declare.

\section{GRANT SUPPORT}

ACM has received financial support through an "Australian Government Research Training Program" scholarship and the Edith Cowan University "Inspiring Minds" scholarship. ESG is supported by a fellowship from the Cancer Research Trust. This study was funded by a Western Australia Cancer Council grant (1100249) and Perpetual/Ramaciotti Health Investment grant to ESG; National Health and Medical Research (NHMRC) grants (1046711 and 1119791) and Department of Health WA grant to MZ; and Spinnaker Health Research Foundation grant to MAK. NKH is supported by an uncoupled NHMRC research fellowship (1117663).

\section{REFERENCES}

1. Horn S, Figl A, Rachakonda PS, Fischer C, Sucker A, Gast A, Kadel S, Moll I, Nagore E, Hemminki K. TERT promoter mutations in familial and sporadic melanoma. Science. 2013; 339:959-61.

2. Kumar R, Heidenreich B, Hosen I, Rachakonda S, Hemminki K. Patterns of Telomerase reverse transcriptase (TERT) promoter mutations in melanoma and bladder cancer. Cancer Res. 2014; 74:S559.

3. Nagore E, Heidenreich B, Requena C, García-Casado Z, Martorell-Calatayud A, Pont-Sanjuan V, Jimenez-Sanchez AI, Kumar R. TERT promoter mutations associate with fastgrowing melanoma. Pigment Cell Melanoma Res. 2016; 29:236-38.

4. Griewank KG, Murali R, Puig-Butille JA, Schilling B, Livingstone E, Potrony M, Carrera C, Schimming T, Möller I, Schwamborn M, Sucker A, Hillen U, Badenas $\mathrm{C}$, et al. TERT promoter mutation status as an independent prognostic factor in cutaneous melanoma. J Natl Cancer Inst. 2014; 106:dju246. 
5. Nagore E, Heidenreich B, Rachakonda S, Garcia-Casado Z, Requena C, Soriano V, Frank C, Traves V, Quecedo E, Sanjuan-Gimenez J, Hemminki K, Landi MT, Kumar R. TERT promoter mutations in melanoma survival. Int $\mathrm{J}$ Cancer. 2016; 139:75-84.

6. Liu T, Wang N, Cao J, Sofiadis A, Dinets A, Zedenius J, Larsson $\mathrm{C}, \mathrm{Xu} \mathrm{D}$. The age-and shorter telomere-dependent TERT promoter mutation in follicular thyroid cell-derived carcinomas. Oncogene. 2014; 33:4978-84.

7. Liu X, Wu G, Shan Y, Hartmann C, Von Deimling A, Xing M. Highly prevalent TERT promoter mutations in bladder cancer and glioblastoma. Cell Cycle. 2013; 12:1637-8.

8. Borah S, Xi L, Zaug AJ, Powell NM, Dancik GM, Cohen SB, Costello JC, Theodorescu D, Cech TR. TERT promoter mutations and telomerase reactivation in urothelial cancer. Science. 2015; 347:1006-10.

9. Vinagre J, Almeida A, Pópulo H, Batista R, Lyra J, Pinto V, Coelho R, Celestino R, Prazeres H, Lima L, Melo M, da Rocha AG, Preto A, et al. Frequency of TERT promoter mutations in human cancers. Nat Commun. 2013; 4:2185.

10. Killela PJ, Reitman ZJ, Jiao Y, Bettegowda C, Agrawal N, Diaz LA Jr, Friedman AH, Friedman H, Gallia GL, Giovanella BC, Grollman AP, He TC, He Y, et al. TERT promoter mutations occur frequently in gliomas and a subset of tumors derived from cells with low rates of selfrenewal. Proc Natl Acad Sci USA. 2013; 110:6021-26.

11. Nault JC, Mallet M, Pilati C, Calderaro J, Bioulac-Sage P, Laurent C, Laurent A, Cherqui D, Balabaud C, ZucmanRossi J. High frequency of telomerase reverse-transcriptase promoter somatic mutations in hepatocellular carcinoma and preneoplastic lesions. Nat Commun. 2013; 4:2218.

12. Yin DT, Yu K, Lu RQ, Li X, Xu J, Lei M, Li H, Wang Y, Liu Z. Clinicopathological significance of TERT promoter mutation in papillary thyroid carcinomas: a systematic review and meta-analysis. Clin Endocrinol (Oxf). 2016; 85:299-305.

13. Huse JT. TERT promoter mutation designates biologically aggressive primary glioblastoma. Neuro-oncol. 2015; 17:5-6.

14. Simon M, Hosen I, Gousias K, Rachakonda S, Heidenreich B, Gessi M, Schramm J, Hemminki K, Waha A, Kumar R. TERT promoter mutations: a novel independent prognostic factor in primary glioblastomas. Neuro-oncol. 2015; $17: 45-52$.

15. Wang K, Liu T, Liu L, Liu J, Liu C, Wang C, Ge N, Ren H, Yan K, Hu S, Björkholm M, Fan Y, Xu D. TERT promoter mutations in renal cell carcinomas and upper tract urothelial carcinomas. Oncotarget. 2014; 5:1829-36. https://doi. org/10.18632/oncotarget.1829.

16. Tsiatis AC, Norris-Kirby A, Rich RG, Hafez MJ, Gocke CD, Eshleman JR, Murphy KM. Comparison of Sanger sequencing, pyrosequencing, and melting curve analysis for the detection of KRAS mutations: diagnostic and clinical implications. J Mol Diagn. 2010; 12:425-32.

17. Diehl F, Schmidt K, Choti MA, Romans K, Goodman S, Li M, Thornton K, Agrawal N, Sokoll L, Szabo SA, Kinzler KW, Vogelstein B, Diaz LA Jr. Circulating mutant DNA to assess tumor dynamics. Nat Med. 2008; 14:985-90.

18. Ascierto PA, Minor D, Ribas A, Lebbe C, O’Hagan A, Arya N, Guckert M, Schadendorf D, Kefford RF, Grob JJ, Hamid O, Amaravadi R, Simeone E, et al. Phase II trial (BREAK2) of the BRAF inhibitor dabrafenib (GSK2118436) in patients with metastatic melanoma. J Clin Oncol. 2013; 31:3205-11.

19. Heitzer E, Ulz P, Geigl JB. Circulating tumor DNA as a liquid biopsy for cancer. Clin Chem. 2015; 61:112-23.

20. Bettegowda C, Sausen M, Leary RJ, Kinde I, Wang Y, Agrawal N, Bartlett BR, Wang H, Luber B, Alani RM, Antonarakis ES, Azad NS, Bardelli A, et al. Detection of circulating tumor DNA in early- and late-stage human malignancies. Sci Transl Med. 2014; 6:224ra24.

21. Tsao SC, Weiss J, Hudson C, Christophi C, Cebon J, Behren A, Dobrovic A. Monitoring response to therapy in melanoma by quantifying circulating tumour DNA with droplet digital PCR for BRAF and NRAS mutations. Sci Rep. 2015; 5:11198.

22. Chang GA, Tadepalli JS, Shao Y, Zhang Y, Weiss S, Robinson E, Spittle C, Furtado M, Shelton DN, KarlinNeumann G, Pavlick A, Osman I, Polsky D. Sensitivity of plasma BRAFmutant and NRASmutant cell-free DNA assays to detect metastatic melanoma in patients with low RECIST scores and non-RECIST disease progression. Mol Oncol. 2016; 10:157-65.

23. Gray ES, Rizos H, Reid AL, Boyd SC, Pereira MR, Lo J, Tembe V, Freeman J, Lee JH, Scolyer RA, Siew K, Lomma C, Cooper A, et al. Circulating tumor DNA to monitor treatment response and detect acquired resistance in patients with metastatic melanoma. Oncotarget. 2015; 6:42008-18. https://doi.org/10.18632/oncotarget.5788.

24. Hindson BJ, Ness KD, Masquelier DA, Belgrader P, Heredia NJ, Makarewicz AJ, Bright IJ, Lucero MY, Hiddessen AL, Legler TC, Kitano TK, Hodel MR, Petersen JF, et al. High-throughput droplet digital PCR system for absolute quantitation of DNA copy number. Anal Chem. 2011; 83:8604-10.

25. Sanmamed MF, Fernández-Landázuri S, Rodríguez C, Zárate R, Lozano MD, Zubiri L, Perez-Gracia JL, MartínAlgarra S, González A. Quantitative cell-free circulating BRAFV600E mutation analysis by use of droplet digital PCR in the follow-up of patients with melanoma being treated with BRAF inhibitors. Clin Chem. 2015; 61:297-304.

26. Santiago-Walker A, Gagnon R, Mazumdar J, Casey M, Long GV, Schadendorf D, Flaherty K, Kefford R, Hauschild A, Hwu P. Correlation of BRAF mutation status 
in circulating-free DNA and tumor and association with clinical outcome across four BRAFi and MEKi clinical trials. Clin Cancer Res. 2016; 22:567-74.

27. Girotti MR, Gremel G, Lee R, Galvani E, Rothwell D, Viros A, Mandal AK, Lim KH, Saturno G, Furney SJ, Baenke F, Pedersen M, Rogan J, et al. Application of Sequencing, Liquid Biopsies, and Patient-Derived Xenografts for Personalized Medicine in Melanoma. Cancer Discov. 2016; 6:286-99.

28. Heidenreich B, Nagore E, Rachakonda PS, Garcia-Casado Z, Requena C, Traves V, Becker J, Soufir N, Hemminki K, Kumar R. Telomerase reverse transcriptase promoter mutations in primary cutaneous melanoma. Nat Commun. 2014; 5:3401.

29. Armbruster DA, Pry T. Limit of blank, limit of detection and limit of quantitation. Clin Biochem Rev. 2008; 29:S49-52.

30. Hayward NK, Wilmott JS, Waddell N, Johansson PA, Field MA, Nones K, Patch AM, Kakavand H, Alexandrov LB, Burke H, Jakrot V, Kazakoff S, Holmes O, et al. Wholegenome landscapes of major melanoma subtypes. Nature. 2017; 545:175-80.

31. Gonzalez de Castro D, Angulo B, Gomez B, Mair D, Martinez R, Suarez-Gauthier A, Shieh F, Velez M, Brophy VH, Lawrence HJ, Lopez-Rios F. A comparison of three methods for detecting KRAS mutations in formalinfixed colorectal cancer specimens. Br J Cancer. 2012; 107:345-51.

32. Reid AL, Freeman JB, Millward M, Ziman M, Gray ES. Detection of BRAF-V600E and V600K in melanoma circulating tumour cells by droplet digital PCR. Clin Biochem. 2015; 48:999-1002.

33. Higgins MJ, Jelovac D, Barnathan E, Blair B, Slater S, Powers P, Zorzi J, Jeter SC, Oliver GR, Fetting J, Emens L, Riley C, Stearns V, et al. Detection of tumor PIK3CA status in metastatic breast cancer using peripheral blood. Clin Cancer Res. 2012; 18:3462-69.

34. Dawson SJ, Tsui DW, Murtaza M, Biggs H, Rueda OM, Chin SF, Dunning MJ, Gale D, Forshew T, MahlerAraujo B, Rajan S, Humphray S, Becq J, et al. Analysis of circulating tumor DNA to monitor metastatic breast cancer. N Engl J Med. 2013; 368:1199-209.

35. Newman AM, Bratman SV, To J, Wynne JF, Eclov NC, Modlin LA, Liu CL, Neal JW, Wakelee HA, Merritt RE, Shrager JB, Loo BW Jr, Alizadeh AA, Diehn M. An ultrasensitive method for quantitating circulating tumor DNA with broad patient coverage. Nat Med. 2014; 20:548-54.
36. Narayan A, Carriero NJ, Gettinger SN, Kluytenaar J, Kozak KR, Yock TI, Muscato NE, Ugarelli P, Decker RH, Patel AA. Ultrasensitive measurement of hotspot mutations in tumor DNA in blood using error-suppressed multiplexed deep sequencing. Cancer Res. 2012; 72:3492-8.

37. Misale S, Yaeger R, Hobor S, Scala E, Janakiraman M, Liska D, Valtorta E, Schiavo R, Buscarino M, Siravegna G, Bencardino K, Cercek A, Chen CT, et al. Emergence of KRAS mutations and acquired resistance to anti-EGFR therapy in colorectal cancer. Nature. 2012; 486:532-6.

38. Lee JH, Long GV, Boyd S, Lo S, Menzies AM, Tembe V, Guminski A, Jakrot V, Scolyer RA, Mann GJ, Kefford RF, Carlino MS, Rizos H. Circulating tumour DNA predicts response to anti-PD1 antibodies in metastatic melanoma. Ann Oncol. 2017; 28:1130-36.

39. Thierry AR, Mouliere F, Gongora C, Ollier J, Robert B, Ychou M, Del Rio M, Molina F. Origin and quantification of circulating DNA in mice with human colorectal cancer xenografts. Nucleic Acids Res. 2010; 38:6159-75.

40. Kamat AA, Bischoff FZ, Dang D, Baldwin MF, Han LY, Lin YG, Merritt WM, Landen CN Jr, Lu C, Gershenson DM, Simpson JL, Sood AK. Circulating cell-free DNA: a novel biomarker for response to therapy in ovarian carcinoma. Cancer Biol Ther. 2006; 5:1369-74.

41. Parkinson CA, Gale D, Piskorz A, Hodgkin C, Biggs H, Addley H, Moyle P, Freeman S, Sala E, Hosking K, Gounaris I, Jimenez-Linan M, Earl HM, et al. Circulating tumour DNA carrying patient-specific mutations in TP53 as an early response biomarker in relapsed high grade serous ovarian cancer. J Clin Oncol. 2016; 34:e23040.

42. Thierry AR, El Messaoudi S, Gahan PB, Anker P, Stroun $M$. Origins, structures, and functions of circulating DNA in oncology. Cancer Metastasis Rev. 2016; 35:347-76.

43. Li Y, Cheng HS, Chng WJ, Tergaonkar V. Activation of mutant TERT promoter by RAS-ERK signaling is a key step in malignant progression of BRAF-mutant human melanomas. Proc Natl Acad Sci USA. 2016; 113:14402-7.

44. Akıncilar SC, Khattar E, Boon PL, Unal B, Fullwood MJ, Tergaonkar V. Long-range chromatin interactions drive mutant TERT promoter activation. Cancer Discov. 2016; 6:1276-91.

45. O'Rourke MG, Johnson M, Lanagan C, See J, Yang J, Bell JR, Slater GJ, Kerr BM, Crowe B, Purdie DM, Elliott SL, Ellem KA, Schmidt CW. Durable complete clinical responses in a phase I/II trial using an autologous melanoma cell/dendritic cell vaccine. Cancer Immunol Immunother. 2003; 52:387-95. 